\title{
Enhanced frequency of neutrophils and inflammatory monocytes and diminished numbers of $T$ and $B$ cells in active pulmonary tuberculosis
}

\author{
N Pavan Kumar ${ }^{1,2^{*}}$, Luke Elizabeth Hanna ${ }^{2}$, MS Jawahar ${ }^{2}$, W Banu Rekha ${ }^{2}$, R Sridhar ${ }^{4}$, Thomas B Nutman ${ }^{3}$, \\ S Subash Babu'
}

From First International Science Symposium on HIV and Infectious Diseases (HIV SCIENCE 2012)

Chennai, India. 20-22 January 2012

\section{Background}

Mycobacterium tuberculosis (M.tb) infects nearly 2 billion people worldwide. Effective immunity against M.tb infection requires co-ordinated responses from both innate and adaptive arms of immunity. To elucidate the immune responses important both in control of infection and in extra-pulmonary dissemination, we examined frequency and/or absolute numbers of T, B and NK cells, dendritic cells and other leucocyte populations in active tuberculosis patients.

\section{Methods}

The frequency as well as absolute numbers of $\mathrm{T}$ cells (CD3+, CD4+, CD8+ T cells), B cells and NK cells as well as the frequency of innate immune cells (neutrophils and monocytes), dendritic cell subsets (pDC \& $\mathrm{mDC}$ ), $\mathrm{T}$ cell subsets (naïve, central and effector memory and regulatory $\mathrm{T}$ cells) was examined by flow cytometry in AFB smear positive pulmonary TB $(\mathrm{Sm}+)$ $(\mathrm{n}=30)$ and AFB smear negative pulmonary TB $(\mathrm{Sm}-)$ $(\mathrm{n}=24)$ and compared with extra- pulmonary TB (EP) $(\mathrm{n}=38)$.

\section{Results}

Among the innate immune subsets, we observed significantly higher frequency of neutrophils and inflammatory monocytes in Sm+ pulmonary TB group when compared with Sm- pulmonary and EP TB group. On the other hand, the absolute numbers of $\mathrm{CD} 3+\mathrm{T}$ cells, CD4 $+T$ cells, CD8 + T cells and B cells were significantly lower in $\mathrm{Sm}+$ when compared with $\mathrm{Sm}$ - and EP TB group.

\section{Conclusion}

Pulmonary TB is characterized by enhanced frequencies of neutrophils and inflammatory monocytes and diminished absolute counts of $\mathrm{T}$ and $\mathrm{B}$ cells, suggesting a crucial role for these cell populations in protection against TB disease development as well as extra-pulmonary dissemination.

\section{Author details \\ ${ }^{1}$ National Institutes of Health - International Center for Excellence in Research, Chennai, India. ${ }^{2}$ National Institute for Research in Tuberculosis, Chennai, India. ${ }^{3}$ Laboratory of Parasitic Diseases, National Institutes of Allergy and Infectious Diseases, National Institutes of Health, Bethesda, Maryland, USA. ${ }^{4}$ Government Stanley Medical College and Hospital, Chennai, India.}

Published: 4 May 2012

doi:10.1186/1471-2334-12-S1-P23

Cite this article as: Kumar et al:: Enhanced frequency of neutrophils and inflammatory monocytes and diminished numbers of $T$ and $B$ cells in active pulmonary tuberculosis. BMC Infectious Diseases 2012 12(Suppl 1): P23.

\footnotetext{
* Correspondence: pavanmedtech@gmail.com

${ }^{1}$ National Institutes of Health - International Center for Excellence in

Research, Chennai, India

Full list of author information is available at the end of the article
}

(c) 2012 Kumar et al; licensee BioMed Central Ltd. This is an Open Access article distributed under the terms of the Creative Commons Attribution License (http://creativecommons.org/licenses/by/2.0), which permits unrestricted use, distribution, and reproduction in any medium, provided the original work is properly cited. 